\title{
Technoeconomic Evaluation for an Installed Small-Scale Photovoltaic Power Plant
}

\author{
Bulent Yaniktepe, Osman Kara, and Coskun Ozalp \\ Engineering Faculty, Department of Energy Systems Engineering, University of Osmaniye Korkut Ata, Fakiusagi, \\ 80000 Osmaniye, Turkey \\ Correspondence should be addressed to Bulent Yaniktepe; byaniktepe@osmaniye.edu.tr
}

Received 24 November 2016; Revised 23 January 2017; Accepted 21 February 2017; Published 30 March 2017

Academic Editor: Cheuk-Lam Ho

Copyright (c) 2017 Bulent Yaniktepe et al. This is an open access article distributed under the Creative Commons Attribution License, which permits unrestricted use, distribution, and reproduction in any medium, provided the original work is properly cited.

Solar energy production and economic evaluation are analyzed, in this study, by using daily solar radiation and average temperature data which are measured for 3 years in the Osmaniye province in Turkey. Besides, this study utilizes the photovoltaic- (PV-) based grid connected to a power plant which has an installed capacity of $1 \mathrm{MW}$ investment in electricity production. Economic values show that the net present value (NPV), the first economic method in the research, is about $111941 \mathrm{USD}$, which is greater than zero. Therefore, the payback year of this investment is approximately 8.3. The second one of these methods, the payback period of the simple payback period (PBP), is 6.27 years. The last method, which is the mean value of the internal rate of return (IRR), is $10.36 \%$. The results of this study show that Osmaniye is a considerable region for the PV investment in electricity production. As a result, investment of a PV system in Osmaniye can be applicable.

\section{Introduction}

Power production from fossil fuel resources has detrimental effects on the environment considering fossil fuel-induced global climate change and air pollution. The increase in the cost of fossil fuels and soaring consumption of energy resources will both play a critical role in the usage of clean energy in many parts of the world in the near future. In the last decade, the trend of electricity generation from renewable energy has taken the place of conventional fossil fuels throughout the world. Solar energy, one of the main sources of renewable energy, is very convenient for electricity generation. In comparison to fossil fuels, solar energy, as a clean, inexhaustible, and immense energy source, is also one of the most promising renewable energies that present a sustainable alternative electricity generation. Furthermore, the areas where solar energy is used intensively, such as electricity generation, water heating, water pumping in agriculture, lightening, and charging, are application areas in which the use photovoltaic (PV) is easy [1-4]. The usage of PV as a renewable source for reliably producing electricity has grown rapidly for more than 30 years as a result of specific national and transnational incentive programs [5]. Moreover, PV as a usage of utilization of renewable energy sources becomes a popular day-by-day account of high modularity, no requirement for additional resource, not having moving parts, and low-maintenance cost. Another advantage of using PV is that when the growing rate of PV usage increases, the cost of the PV electricity generation decreases steadily [6]. Studies have showed that photovoltaic systems will be broadly used in the future, considering the rapidly decreasing cost of photovoltaic systems. Because price analysis is very important for energy marketing, a review of the cost potential factors on photovoltaic panels was realized, and the expected cost potential of photovoltaic systems was examined considering numerous studies [7].

Researchers have started to carry out economic and technical analyses of a PV power plant to be installed in Turkey. In this context, the producing capacity of grid-connected photovoltaic power plants for 135 locations in Turkey has been investigated [8]. This study has found that although Osmaniye, Dalaman, and Koycegiz have the highest energy generation, Tosya, Gumushane, and Artvin have the lowest energy production. Three separate PV panels for a PV power 
TABLE 1: Solar energy potential for subregions in Turkey [16].

\begin{tabular}{|c|c|c|c|c|c|c|}
\hline & \multirow[b]{2}{*}{$\begin{array}{c}\text { Average radiation } \\
\left(\mathrm{kWh} / \mathrm{m}^{2} / \text { year }\right)\end{array}$} & \multicolumn{5}{|c|}{ Sunshine duration period } \\
\hline & & $\begin{array}{c}\text { Maximum } \\
\left(\mathrm{kWh} / \mathrm{m}^{2} / \text { year }\right)\end{array}$ & $\begin{array}{c}\text { Minimum } \\
\left(\mathrm{kWh} / \mathrm{m}^{2} \text { year }\right)\end{array}$ & $\begin{array}{l}\text { Average } \\
\text { (h/year) }\end{array}$ & $\begin{array}{c}\text { Maximum } \\
\text { (h/year) }\end{array}$ & $\begin{array}{c}\text { Minimum } \\
\text { (h/year) }\end{array}$ \\
\hline $\begin{array}{l}\text { Southeastern } \\
\text { Anatolia }\end{array}$ & 1492 & 2250 & 600 & 3016 & 408 & 127 \\
\hline Mediterranean & 1453 & 2112 & 588 & 2924 & 360 & 102 \\
\hline General Anatolia & 1434 & 2112 & 504 & 2712 & 381 & 98 \\
\hline Aegean & 1407 & 2028 & 492 & 2726 & 371 & 96 \\
\hline East Anatolia & 1395 & 2196 & 588 & 2694 & 374 & 167 \\
\hline Marmara & 1144 & 1992 & 396 & 2528 & 351 & 88 \\
\hline Black Sea & 1086 & 1704 & 408 & 1966 & 274 & 84 \\
\hline
\end{tabular}

plant which has the capacity of $3 \mathrm{kWp}$ for Kahramanmaras are investigated to obtain optimal PV type in terms of thinfilm, monocrystalline, and polycrystalline silicon PV panels. The investigation concluded that the system consisting of polycrystals is the most suitable type for the region in terms of the shortest breakeven point for the investment [9]. Solar power generation potential in 2009 for Istanbul was evaluated using the parameters of technical measurements. Moreover, the results obtained using different tariffs, such as time-ofuse and feed-in tariffs, show that electricity payments of customers can be decreased by using solar PV systems by more than $40 \%$ [10].

Economic analyses of electricity generation from solar renewable energy sources in the world have been investigated by several researches. Hrayshat and Al-Soud [11] show that the total PV installed capacity in Jordan is $82 \mathrm{kWp}$, generating a total of $182.5 \mathrm{MWh}$ of electricity each year. They use a PV system which has a $5 \mathrm{MWp}$ installed capacity for energy production. Also, economic analysis is calculated using monthly mean values of temperature, global solar radiation, and latitude in RETScreen software.

Furthermore, Al-Badi et al. [12] utilize a $5 \mathrm{MW}$ solar PV power plant for 25 locations in Oman, and the mean energy production value from the PV power plant is found to be $7700 \mathrm{MWh}$ for each year. They conclude that the capacity factor varies between $20 \%$ and $14 \%$ and the cost of electricity is $250 \mathrm{USD} / \mathrm{MWh}$ on average. Another study carries out the economic analysis of a $1.2 \mathrm{MW}$ capacity grid-connected photovoltaic (PV) power plant installed at the Colorado State University-Pueblo [13]. Cash flow economic analysis is performed on a $1 \mathrm{MWp}$ PV power station in Farafenni [14]. Quansah et al. [15] develop analytical models to conduct a technical and economic comparison of grid-charged battery-inverter systems (GBIS) and solar PV with battery storage systems (SPVS). In the study, GBIS is compared with an alternative approach that uses SPVS facility and is designed to meet half (50\%) of the user's regular load.

As a result, it is the objective of this paper to verify the economic feasibility of implementing PV solar power in Osmaniye and to examine the economic benefit of solar energy. The rest of the paper will be structured according to the following: Section 1 presents Osmaniye and Turkey's annual solar radiation potential. Section 2 identifies the
TABLE 2: Feed-in tariff and incentives, locally manufactured components, and PV [17].

\begin{tabular}{lc}
\hline Locally manufactured component & Bonus (USD cent $/ \mathrm{kWh}$ ) \\
\hline PV panel integration and production & 0.8 \\
PV modules & 1.3 \\
PV module cells & 3.5 \\
Inverter & 0.6 \\
Material which focuses radiation on & 0.5 \\
PV module & $13.3+6.7=20$ \\
Total &
\end{tabular}

location of Osmaniye and determines the status of the photovoltaic solar modules. Section 3 examines the economic feasibility of Osmaniye. Section 3 also evaluates the economic viability of solar energy. Finally, Section 4 presents the main conclusions and recommendations.

\section{Materials and Methods}

2.1. Solar Energy Potential of Osmaniye. The location of Turkey has a considerable solar energy potential in terms of sunshine duration to produce electricity using PV. The yearly average solar radiation is $3.6 \mathrm{kWh} / \mathrm{m}^{2} /$ day, and the total yearly radiation period is approximately $2640 \mathrm{~h}$, which is sufficient to provide adequate energy for solar applications. The technical and economic usages of solar energy in Turkey are 6105 and 305 billion kWh, respectively. Moreover, the solar energy breakdown in Turkey is shown in Table 1 in terms of subregions. As can be seen from Table 1, the highest average radiation values are in the Southeastern Anatolia and Mediterranean regions, which are 1492 and $1453 \mathrm{kWh} / \mathrm{m}^{2} /$ year, respectively [16].

Renewable energy has been one of the hot topics on Turkey's energy agenda. Significant progress has been made in the field of renewable energy starting from 2005, after the enactment of the Law on Utilization of Renewable Energy Resources for the Purpose of Generating Electrical Energy (Renewable Energy Law (REL)). Investments in renewable energy technologies remained limited between 2005 and 2010 due to the lack of secondary legislation and relatively low feed-in tariff prices. The RE Law of 2010 offers 


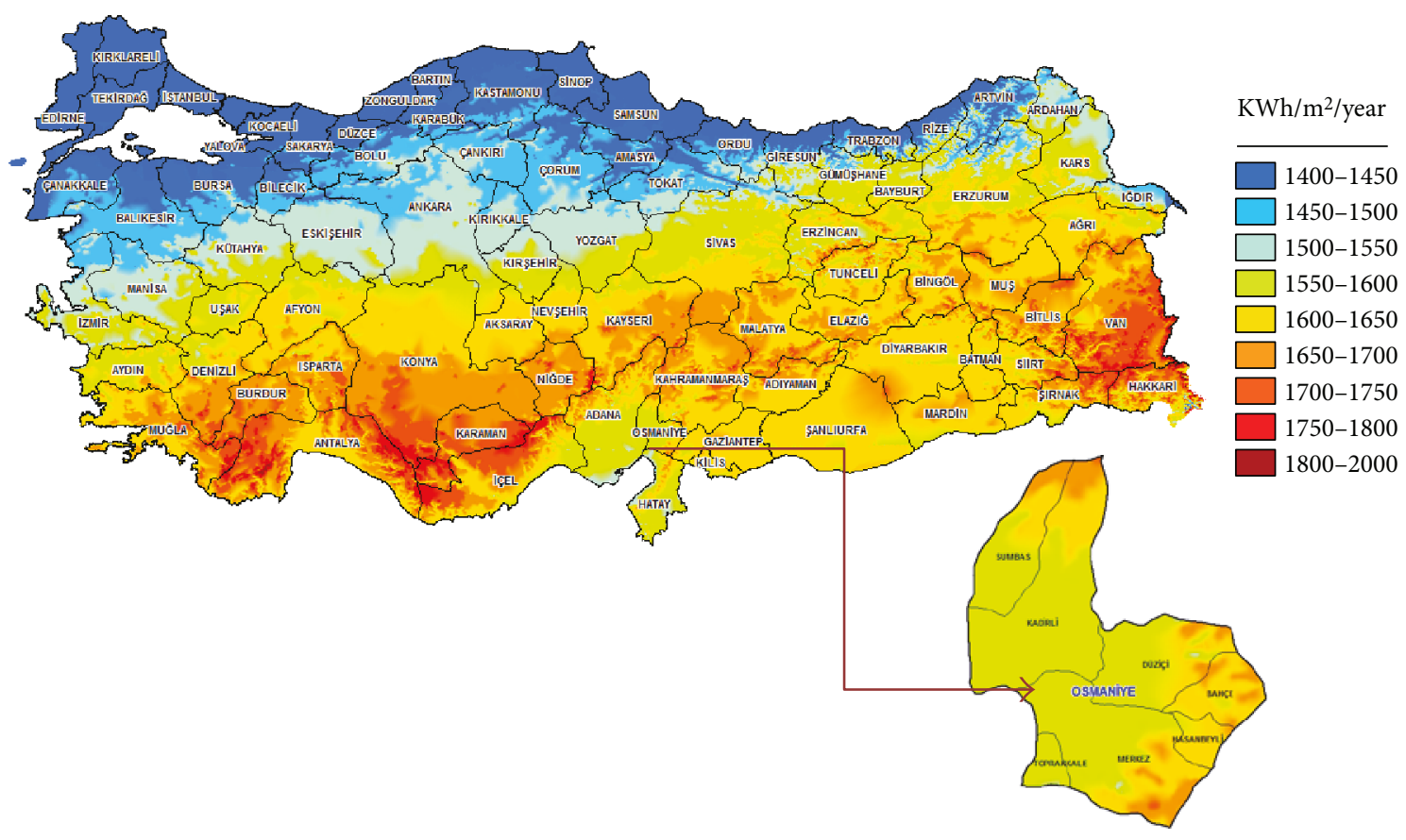

Figure 1: Annual solar energy capacity and location of Osmaniye in Turkey [18].

renewable electricity producers higher FIT rate schemes if they use local components in their projects. Currently, PVs dominate the solar market and global PV installed capacity grew by $74 \%$ in 2011. Support and incentives for PV investment in REL is given in Table 2. Generous subsidies around the world have been the main drivers of this significant growth. Even though prices of PVs have fallen dramatically over the years, additional reductions are needed for further implementation [17].

Osmaniye, 37.05 north and 36.14 east, is located in the Mediterranean region in Turkey, as shown in Figure 1 [18]. Solar radiation data in this study were measured every 5 minutes from 22 June 2012 to 01 June 2015 by using a meteorological measuring device (Vantage Pro2 Weather Station) located at the building of the Energy Systems Engineering Department in the campus of Osmaniye Korkut Ata University. A meteorological measuring device was mounted $20 \mathrm{~m}$ high from ground level. After the data was measured, the solar energy potential was calculated as averaged values of hourly, daily, monthly, and yearly.

As seen from Figure 2(a), the maximum and minimum total solar radiation occurred in 2013 and 2012, respectively. In addition, the highest monthly average daily radiation of $7.3 \mathrm{kWh} / \mathrm{m}^{2} /$ day was recorded in the month of June, whereas the lowest monthly average solar radiation was $1.6 \mathrm{kWh} / \mathrm{m}^{2} /$ day in December of 2012 . It is understood from Figure 1 that monthly averaged values of global solar radiation stay nearly constant every month for each year. As a result, the total value of measured solar radiation based on the year 2013 was about $1.7 \mathrm{MWh} / \mathrm{m}^{2} /$ year for one complete year. Hourly measured monthly average daily global solar radiation during the year 2014 is also shown in Figure 2(b). As can be seen from this figure, the highest and lowest values of monthly averaged total global solar radiation are $695 \mathrm{~W} / \mathrm{m}^{2}$ and $476 \mathrm{~W} / \mathrm{m}^{2}$ in 2014 . Considering the monthly values, Figure 2(b) also indicates that the daily mean and maximum solar radiation values are generally higher in summer (May-June-July), whereas comparatively, lower values are seen in winter months (November-DecemberJanuary).

2.2. Solar PV System Description and Economic Feasibility Analysis. Global radiation, sunshine duration, and temperature as measured data are generally needed to produce electricity with a photovoltaic power plant in a selected region. Therefore, values of average daily measurement data from the meteorological measuring device in Osmaniye are given in Table 3 . The table shows that the value of monthly measured average radiation is $136892 \mathrm{kWh} / \mathrm{m}^{2}$; the value of annual solar duration is $2959 \mathrm{~h}$, and the value of annual average temperature is $18.3^{\circ} \mathrm{C}$. Moreover, it is clear that Osmaniye has a significant solar energy potential to produce electricity.

PV modules can be collocated to form a solar array to provide the specific power at a specified voltage and current. In this context, as boundary conditions of this study, a $250 \mathrm{~W}$ peak PV module, which encloses polycrystalline silicon solar cells [20], is considered for obtaining $1 \mathrm{MW}$ installed capacity of a power plant which includes 3986 modules calculated using the technical specifications in Table 4. If the PV system is installed on the roof of the building, the roof will be assumed to be a shed roof of $18^{\circ}$ tilt made, covering a surface of approximately $6800 \mathrm{~m}^{2}$ for $1 \mathrm{MW}$ installed capacity.

In the economic viability aspect, the net present value (NPV), payback period (PBP) method, and internal rate of return (IRR) are analyzed in this study. Moreover, net present value (NPV) as an economic indicator is defined as the 


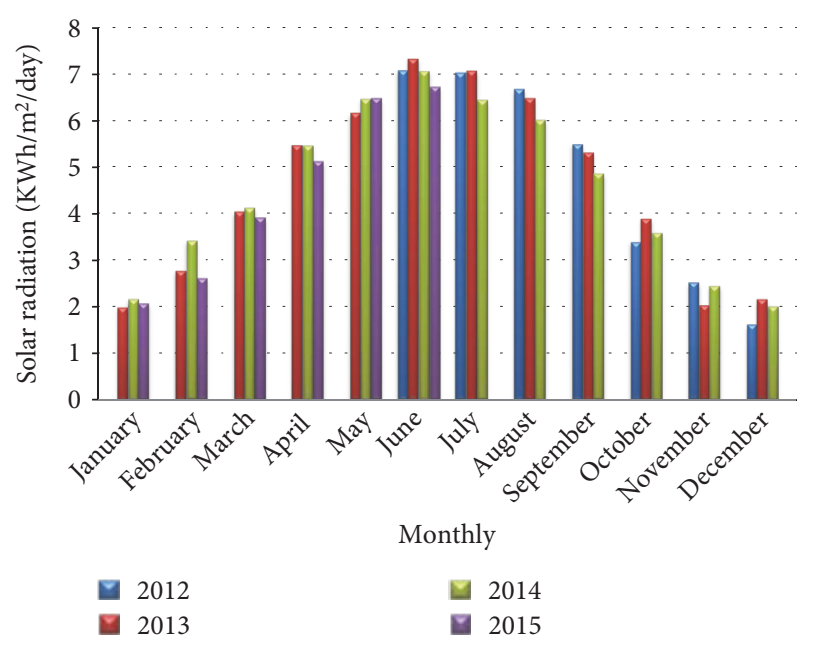

(a)

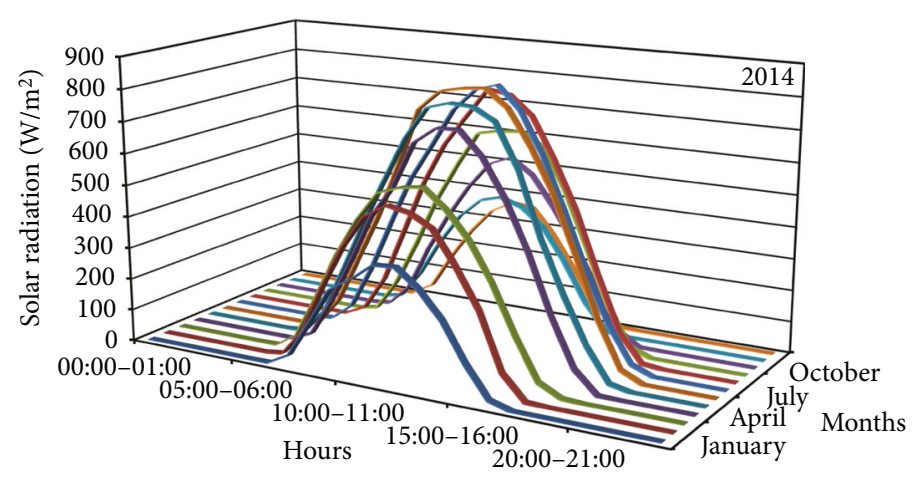

(b)

FIgURE 2: (a) Monthly averages of daily solar radiation throughout 2012-2015. (b) Hourly measured monthly average daily global radiation for 2014 .

TABLE 3: The values of daily average measurement data.

\begin{tabular}{lccc}
\hline Months & $\begin{array}{c}\text { Daily average } \\
\text { radiation } \\
\left(\mathrm{kWh} / \mathrm{m}^{2}\right)\end{array}$ & $\begin{array}{c}\text { Daily average } \\
\text { sunshine duration } \\
(\mathrm{h})[18]\end{array}$ & $\begin{array}{c}\text { Daily average } \\
\text { temperature } \\
\left({ }^{\circ} \mathrm{C}\right)[19]\end{array}$ \\
\hline January & 2.09 & 4.57 & 8.6 \\
February & 3.10 & 5.66 & 9.7 \\
March & 4.1 & 6.76 & 12.7 \\
April & 5.48 & 7.87 & 16.9 \\
May & 6.31 & 9.83 & 21.1 \\
June & 7.16 & 11.39 & 25.2 \\
July & 6.85 & 11.79 & 27.8 \\
August & 6.40 & 11.19 & 28.4 \\
September & 5.23 & 10.15 & 25.3 \\
October & 3.64 & 7.78 & 20.4 \\
November & 2.35 & 5.92 & 13.8 \\
December & 1.94 & 4.24 & 9.7 \\
\hline
\end{tabular}

value of all future cash flows, calculated at the discount rate. Positive NPV represents an indicator of a potentially feasible project [21]. Sowe et al. [14] also provided the following equation:

$$
\sum_{n=0}^{N} \frac{B_{n}}{(1+i)^{n}}-\sum_{n=0}^{N} \frac{C_{n}}{(1+i)^{n}}=\mathrm{PVB}-\mathrm{PVC}
$$

where $B_{n}=$ expected benefit at the end of the year $n$, $C_{n}=$ expected cost at the end of year $n, i=$ discountrate, $n=$ project duration in years, $N=$ project period, $\mathrm{PVB}=$ present value benefit, and $\mathrm{PVC}=$ present value cost. The payback period (PBP), which is the second economic method applied in this study, is substantially indicated by the payback period of the project as stated in (2). The project investment
TABLE 4: Technical specifications of a photovoltaic module used [20].

\begin{tabular}{lccc}
\hline $\begin{array}{l}\text { Item } \\
\text { description }\end{array}$ & $\begin{array}{c}\text { Item } \\
\text { specification }\end{array}$ & $\begin{array}{c}\text { Item } \\
\text { description }\end{array}$ & $\begin{array}{c}\text { Item } \\
\text { specification }\end{array}$ \\
\hline $\begin{array}{l}\text { Module } \\
\text { number }\end{array}$ & BYD 250P6-30 & $\begin{array}{c}\text { Short-circuit } \\
\text { current } \\
\text { Open-circuit } \\
\text { current }\end{array}$ & $8.98 \mathrm{~A}$ \\
Efficiency & 15.37 percent & $38 \mathrm{~V}$ \\
$\begin{array}{l}\text { Rated power } \\
\left(P_{\max }\right)\end{array}$ & $250 \mathrm{~W}$ & Frame area & $1.63 \mathrm{~m}^{2}$ \\
$\begin{array}{l}\text { Voltage } \\
\text { at } P_{\max }\end{array}$ & $30.40 \mathrm{~V}$ & $\begin{array}{c}\text { Dimension } \\
(\text { mm })\end{array}$ & $1640 \times 992 \times 50$ \\
$\begin{array}{l}\text { Current } \\
\text { at } P_{\max }\end{array}$ & $8.22 \mathrm{~A}$ & Weight & $19.6 \mathrm{~kg}$ \\
\hline
\end{tabular}

is unacceptable with respect to economics when the PBP presents a high value (long payback periods). PBP does not incorporate the time value of money; moreover, assumptions on discount or interest rates are not required. Otherwise, the shorter PBP indicates the better investment. It is well known that the criterion of PBP value for the availability is higher than the profitability of the PV project. PBP is shown as follows $[14,22]$ :

$$
\mathrm{PBP}=\frac{\text { Initial investment }(\mathrm{USD})}{\text { Annual saving (USD/years) }}=\text { years. }
$$

The last applied economic method is the internal rate of return (IRR), calculated by the subtraction of the total present value benefit from the total present value cost. As the IRR is greater than the discount rate, the PV project is considered as satisfactory and worthwhile. The IRR is defined in (3) where $i=\operatorname{IRR}[14,23]$. 


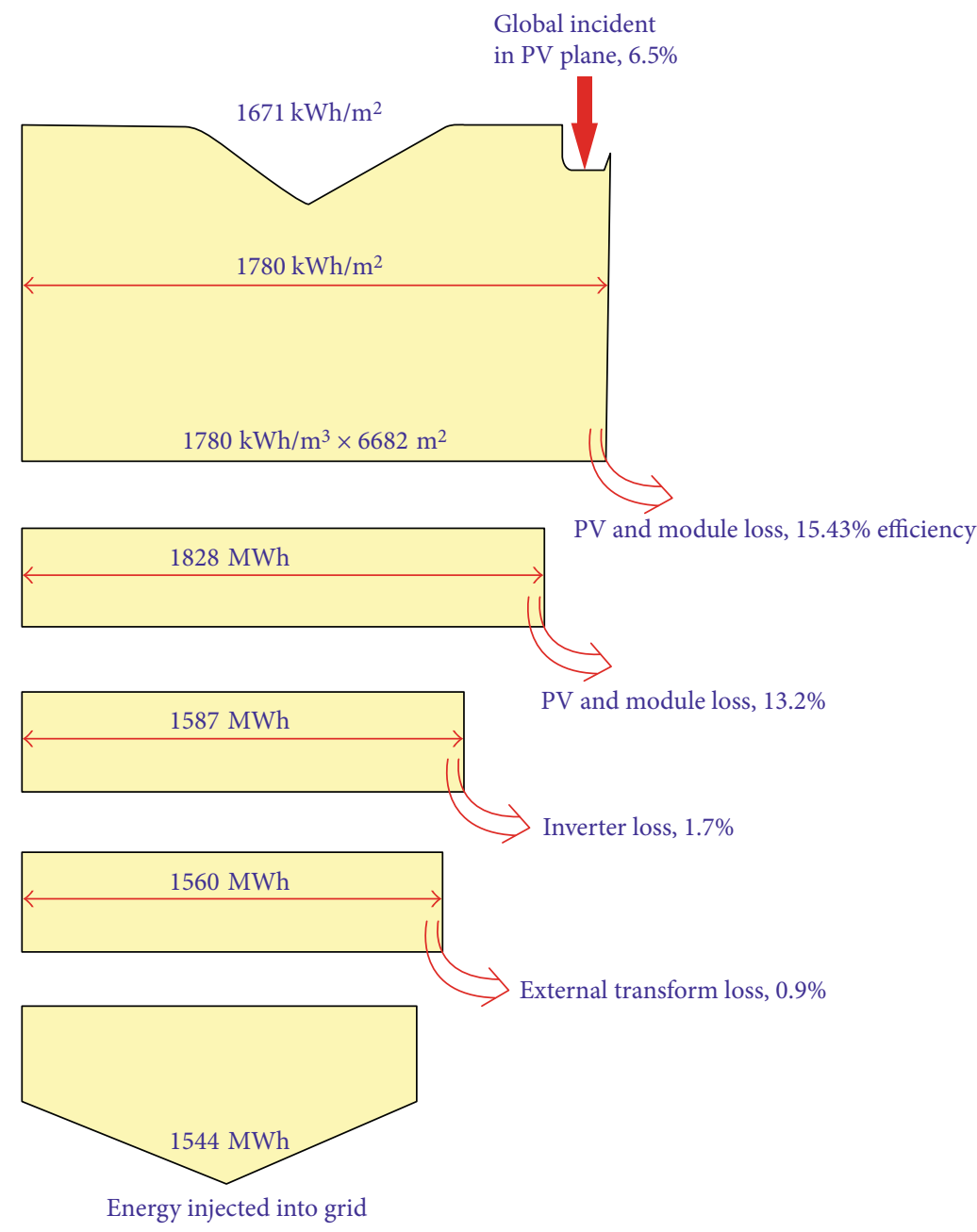

FIGURE 3: Electricity generation of a proposed solar PV system considering losses [24].

TABLE 5: Assumption of various interest rates used in the economic feasibility [25].

\begin{tabular}{lc}
\hline Item description & Value \\
\hline Interest rate (TL) & $10.79 \%$ \\
Inflation rate (TL) & $2.96 \%$ \\
Discount rate (TL) & $7.6 \%$ \\
Photovoltaic panel yield loss & $8 \%$ \\
Project life & 25 years \\
\hline
\end{tabular}

$$
\sum_{n=0}^{N} \frac{B_{n}}{(1+i)^{n}}-\sum_{n=0}^{N} \frac{C_{n}}{(1+i)^{n}}=0
$$

\section{Results and Discussions}

Total investment cost, life cycle of panel sand inverters, fixed operation, maintenance, repairing and utilizing costs, purchasing price offered by the government, and increasing energy costs were considered while calculating the economic
TABLE 6: Cost and economic assumption of the PV power plant [1].

\begin{tabular}{lcc}
\hline Item description & Cost $(\$)$ & $\%$ of total cost \\
\hline Feasibility study & 9012 & $0.7 \%$ \\
Development cost & 6437 & $0.5 \%$ \\
Engineering cost & 5150 & $0.4 \%$ \\
Solar PV equipment & 1125257 & $87.4 \%$ \\
Balance of power plant & 102998 & $8 \%$ \\
Miscellaneous & 38624 & $3 \%$ \\
Total initial cost & 1287479 & 100 \\
Annual operation and maintenance & 5000 & Annual \\
Depreciation & 81000 & Annual \\
\hline
\end{tabular}

viability of a proposed $1 \mathrm{MW}$ solar PV system. Thus, the costs and benefits of solar PV system which will generate electricity into are analyzed and assessed based on the government incentive in Turkey. In this study, it is seen from Figure 2 that measured annual average solar radiation to the horizontal surface is $1671 \mathrm{kWh} / \mathrm{m}^{2}$. As shown in Figure 3, PV and module loss, inverter loss, and external transform loss are 
TABLE 7: Economic indicators for $1 \mathrm{MW}$ solar PV system for NPV.

\begin{tabular}{|c|c|c|c|c|c|c|c|c|c|c|c|}
\hline \multicolumn{12}{|c|}{ Economic indicators for $1 \mathrm{MW}$ solar PV system for NPV (USD) } \\
\hline & & & & & & Years & & & & & \\
\hline & 0 & 1 & 2 & 3 & 4 & 5 & 6 & 7 & 8 & 9 & 10 \\
\hline Income & & 204961 & 203692 & 202473 & 201308 & 200201 & 199156 & 198179 & 197275 & 196449 & 195709 \\
\hline Expenses & & 111204 & 111204 & 111204 & 111204 & 111204 & 151188 & 150992 & 150810 & 150643 & 150494 \\
\hline Depreciation expenses & & 80924 & 80924 & 80924 & 80924 & 80924 & 80924 & 80924 & 80924 & 80924 & 80924 \\
\hline Cash flow & & 174681 & 173412 & 172193 & 171028 & 169921 & 128892 & 128111 & 127389 & 126730 & 126139 \\
\hline Present value of cash flows & -1287479 & 162343 & 149780 & 138222 & 127590 & 117811 & 83053 & 76719 & 70898 & 65550 & 60635 \\
\hline Scrap cost (10 years later) & 346819 & & & & & & & & & & \\
\hline Present value & 1399420 & & & & & & & & & & \\
\hline Net present value & 111941 & & & & & & & & & & \\
\hline
\end{tabular}

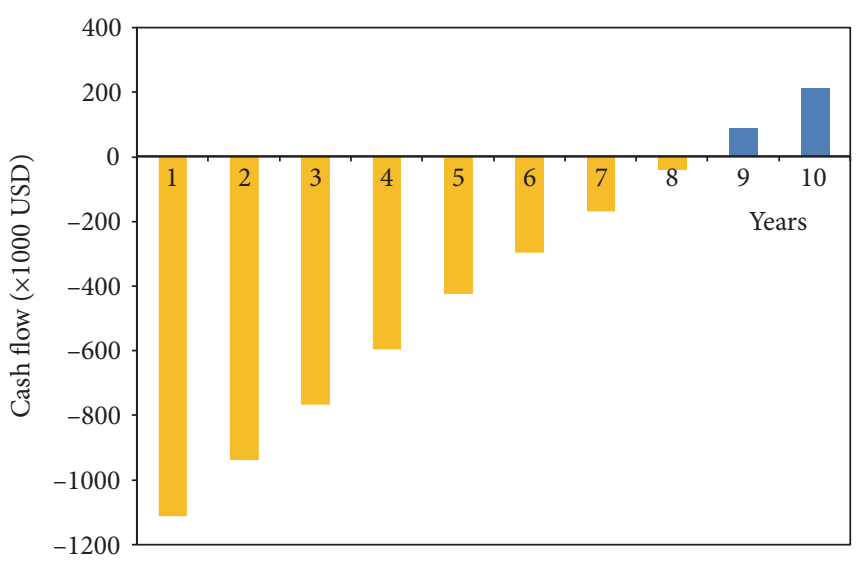

FIgUre 4: Cumulative cash flow, NPV for PV power plant.

taken into account while determining total generation electricity of a PV system. Using the study of Verma and Singhal [24], energy injected into grid is calculated as $1544 \mathrm{MWh} /$ year in Osmaniye. The input economical parameters for these three economical methods are summarized in Table 5. The costs of the main parts of the solar PV system are given in Table 6 .

PV panels, transportation, and installation are the main equipment for solar PV investment, and its percentage is around 87.4. Balance of plant cost, as the second higher investment cost, accounts for approximately $8 \%$ of the total cost. All of these costs and interest rates given in Tables 5 and 6 were used for economic feasibility analysis in this research [1].

NPV is the difference between the present value of investment cash inflow and investment cost. If the NPV is a positive value, the project is potentially feasible. Also, NPV determines whether the project is generally an acceptable investment or not. Table 7 shows that the NPV is greater than zero when the year is approximately 8.3 , which is the payback year of this investment. Besides, Figure 4 shows that positive and negative cash flow changes by years.

Table 8 presents the second economic method which is the simple payback method (PBP), and economic indicators for PBP are given in this table. The payback period is 6.27.
TABLE 8: Economic indicators for PBP.

\begin{tabular}{lc}
\hline Description & Value (USD) \\
\hline The total annual benefit & 68926 \\
Total initial cost & 1287479 \\
Scrap value & 346819 \\
Depreciation & 80924 \\
Repayment period (year) & 6.27 \\
\hline
\end{tabular}

TABLE 9: Economic indicators for IRR.

\begin{tabular}{lc}
\hline Discount rate & NPV \\
\hline$i_{1}=10 \%$ & +13453 \\
$i_{2}=12 \%$ & -23277 \\
\hline
\end{tabular}

The quicker the regaining of the cost of an investment is, the more desirable the investment for the basic assumption of PBP is. Consequently, the result of PBP for Osmaniye seems feasible.

The development of a PV project would be acceptable if the IRR is equal to or greater than the required rate of return. Table 9 shows the IRR indicators and the value of the calculated IRR for Osmaniye. As can be seen from this table, the IRR is $10.36 \%$, greater than the discount rate. So, the considered investment appears profitable.

\section{Conclusion}

Photovoltaic application can provide clean and reliable energy, without noise, and is an environmentally friendly source of power. In addition, the cost of photovoltaic energy technology is gradually decreasing as the market demand and production of PV systems are increasing. This study makes an economic analysis of a solar PV grid-connected system for $1 \mathrm{MW}$ electricity generation plant in Osmaniye and the technical potential of solar PV electricity generation. This research underlined the obtained results given below.

The total value of measured solar radiation was about 1.7 MWh $/ \mathrm{m}^{2} /$ year for one complete year. The highest monthly average daily radiation was found to be $7.3 \mathrm{kWh} /$ 
$\mathrm{m}^{2} /$ day, whereas the lowest monthly average solar radiation was $1.6 \mathrm{kWh} / \mathrm{m}^{2} /$ day.

The NPV was found to vary between $\$ 100000$ and $\$ 120000$, while the mean value remained as $\$ 111941$. The payback year of this investment in terms of NPV is approximately 8.3, and the PBP varied between 6 and 7 years. PBP was calculated as 6.27 years, and the mean value of the internal rate of return (IRR) was determined as $10.36 \%$. As a result, based on economic indicators and technical results, Osmaniye was found to be the best site for the development of a PV-based power plant.

\section{Conflicts of Interest}

The authors declare that they have no conflicts of interest.

\section{Acknowledgments}

The authors acknowledge the financial support of The Office of Scientific Research Projects of Osmaniye Korkut Ata University for the funding under Project no. OKÜBAP-2014-PT3-038. It is gratefully acknowledged.

\section{References}

[1] S. Rehman, M. A. Bader, and S. A. Al-Moallem, "Cost of solar energy generated using PV panels," Renewable and Sustainable Energy Reviews, vol. 11, no. 8, pp. 1843-1857, 2007.

[2] V. V. Tyagi, N. L. Panwar, N. A. Rahim, and R. Kothari, "Review on solar air heating system with and without thermal energy storage system," Renewable and Sustainable Energy Reviews, vol. 16, no. 4, pp. 2289-2303, 2012.

[3] C. Ertekin, F. Evrendilek, and R. Kulcu, "Modeling spatiotemporal dynamics of optimum tilt angles for solar collectors in Turkey," Sensors, vol. 8, no. 5, pp. 2913-2931, 2008 a.

[4] C. Ertekin, R. Kulcu, and F. Evrendilek, "Techno-economic analysis of solar water heating systems in Turkey," Sensors, vol. 8, no. 2, pp. 1252-1277, 2008b.

[5] International Energy Agency (IEA), "Report IEA-PVPS T1-24:2014," PVPS Report Snapshot of Global PV 1992-2013 Preliminary Trends Information from the IEA PVPS Programme, 2014.

[6] A. Bianchini, M. Gambuti, M. Pellegrini, and C. Saccani, "Performance analysis and economic assessment of different photovoltaic technologies based on experimental measurements," Renewable Energy, vol. 85, pp. 1-11, 2016.

[7] M. S. Cengiz and M. S. Mami, "Price-efficiency relationship for photovoltaic systems on a global basis," International Journal of Photoenergy, vol. 2015, Article ID 256101, p. 12, 2015.

[8] N. Caglayan, C. Ertekin, and F. Evrendilek, "Spatial viability analysis of grid-connected photovoltaic power systems for Turkey," International Journal of Electrical Power \& Energy Systems, vol. 56, pp. 270-278, 2014.

[9] S. Yılmaz, H. R. Ozcalık, S. Kesler, F. Dincer, and B. Yelmen, "The analysis of different PV power systems for the determination of optimal PV panels and system installation-a case study in Kahramanmaras, Turkey," Renewable and Sustainable Energy Reviews, vol. 52, pp. 1015-1024, 2015.

[10] A. Batman, F. G. Bagriyanik, Z. E. Aygen, O. Gul, and M. Bagriyanik, "A feasibility study of grid-connected photovoltaic systems in İstanbul, Turkey," Renewable and Sustainable Energy Reviews, vol. 16, no. 8, pp. 5678-5686, 2012.

[11] E. S. Hrayshat and M. S. Al-Soud, "Solar energy in Jordan: current state and prospects," Renewable Energy, vol. 8, no. 2, pp. 193-200, 2004.

[12] A. H. Al-Badi, M. H. Albadi, A. M. Al-Lawati, and A. S. Malik, "Economic perspective of PV electricity in Oman," Energy, vol. 36, no. 1, pp. 226-232, 2011.

[13] A. M. Paudel and H. Sarper, "Economic analysis of a gridconnected commercial photovoltaic system at Colorado State University-Pueblo," Energy, vol. 52, pp. 289-296, 2013.

[14] S. Sowe, N. Ketjoy, P. Thanarak, and T. Suriwong, “Technical and economic viability assessment of PV power plants for rural electrification in the Gambia," Energy Procedia, vol. 52, pp. 389-398, 2014.

[15] D. A. Quansah, M. S. Adaramola, I. A. Edwin, and E. K. Anto, "An assessment of grid-charged inverter-battery systems for domestic applications in Ghana," Journal of Solar Energy, vol. 2016, Article ID 5218704, p. 11, 2016.

[16] E. Toklu, M. S. Güney, M. Işık, O. Comaklı, and K. Kaygusuz, "Energy production, consumption, policies and recent developments in Turkey," Renewable and Sustainable Energy Reviews, vol. 14, no. 4, pp. 1172-1186, 2010.

[17] Renewable Energy \& Environmental Technologies, Republic of Turkey Prime Ministry Investment Support and Promotion Agency, 2013, http://www.invest.gov.tr/ enUS/infocenter/publications/Documents/environmental.tech. renewable.industry.pdf.

[18] Yenilenebilir Enerji Genel Müdürlüğü, Güneş Enerjisi Potansiyel Atlası (GEPA), 2016, April 2016, http://www.eie.gov.tr/ MyCalculator/Default.aspx.

[19] Turkish State Meteorological Service, 2016, April 2016, http://www.mgm.gov.tr/veridegerlendirme/il-ve-ilceler-istatis tik.aspx?m=OSMANIYE.

[20] Photovoltaic Solar Module Properties, 2016, April 2016, http:// www.byd.com/pv/module.html.

[21] M. A. H. Mondal and A. K. M. Sadrul Islam, "Potential and viability of grid-connected solar PV system in Bangladesh," Renewable Energy, vol. 36, no. 6, pp. 1869-1874, 2011.

[22] S. Rodrigues, R. Torabikalaki, F. Faria et al., "Economic feasibility analysis of small scale PV systems in different countries," Solar Energy, vol. 131, pp. 81-95, 2016.

[23] L. B. Jose and D. Rodolfo, "Economical and environmental analysis of grid connected photovoltaic system in Spain," Renewable Energy, vol. 31, no. 8, pp. 1107-1128, 2006.

[24] A. Verma and S. Singhal, "Solar PV performance parameter and recommendation for optimization of performance in large scale grid connected solar PV plant-case study," Journal of Energy Power Sources, vol. 2, no. 1, pp. 40-53, 2015.

[25] T. C. M. Bankas1, Enflasyon Raporu 2016-1, 2016, April 2016, http://www.tcmb.gov.tr/wps/wcm/connect/TCMB+TR/ TCMB+TR/Main+Menu/Istatistikler/Piyasa+Verileri/. 

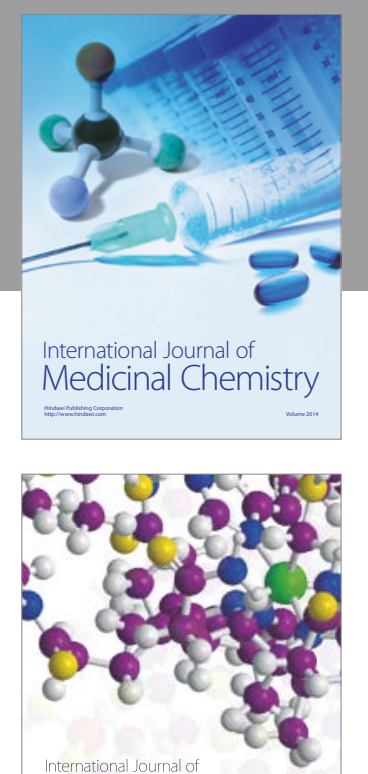

Carbohydrate Chemistry

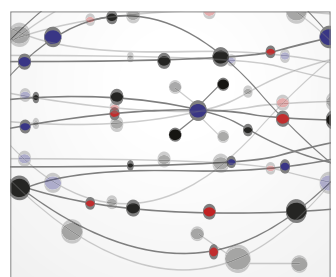

The Scientific World Journal
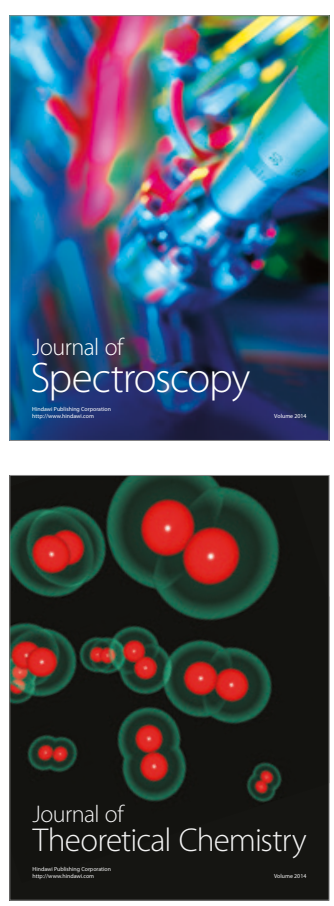
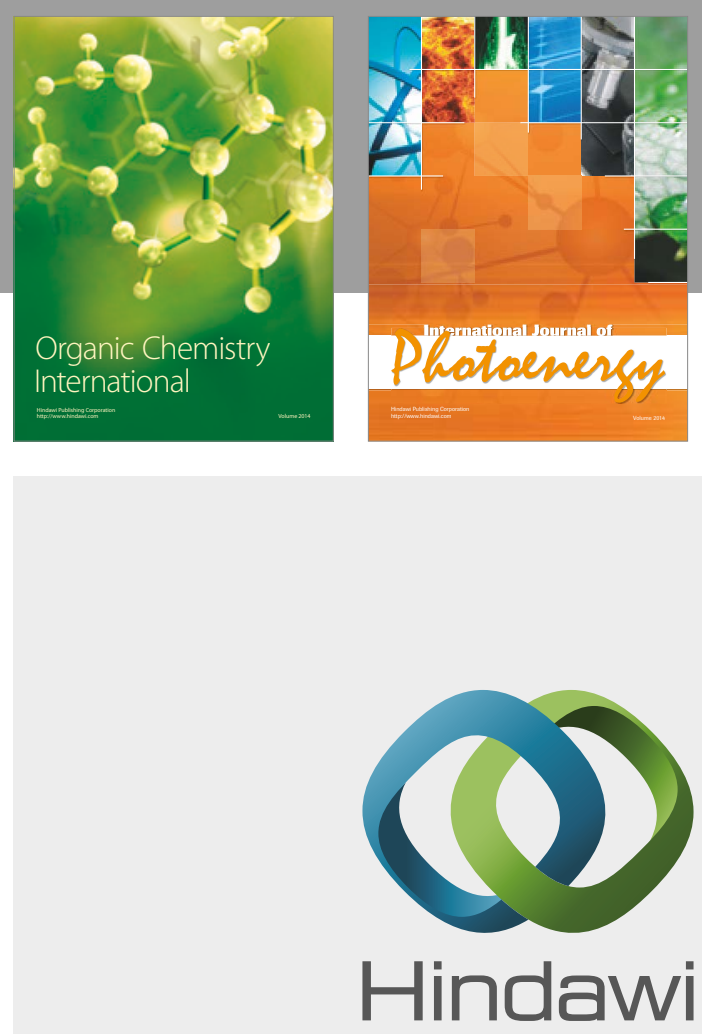

Submit your manuscripts at

https://www.hindawi.com

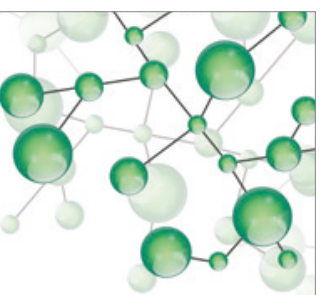

International Journal of

Inorganic Chemistry

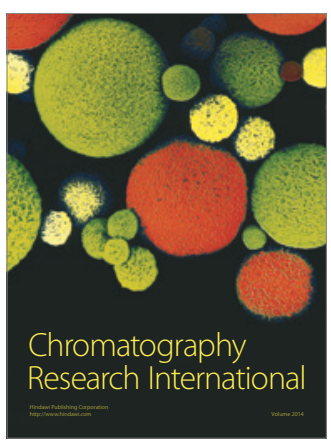



Applied Chemistry
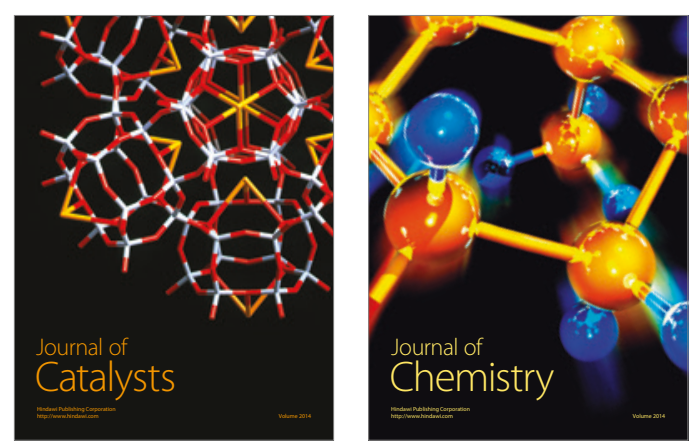
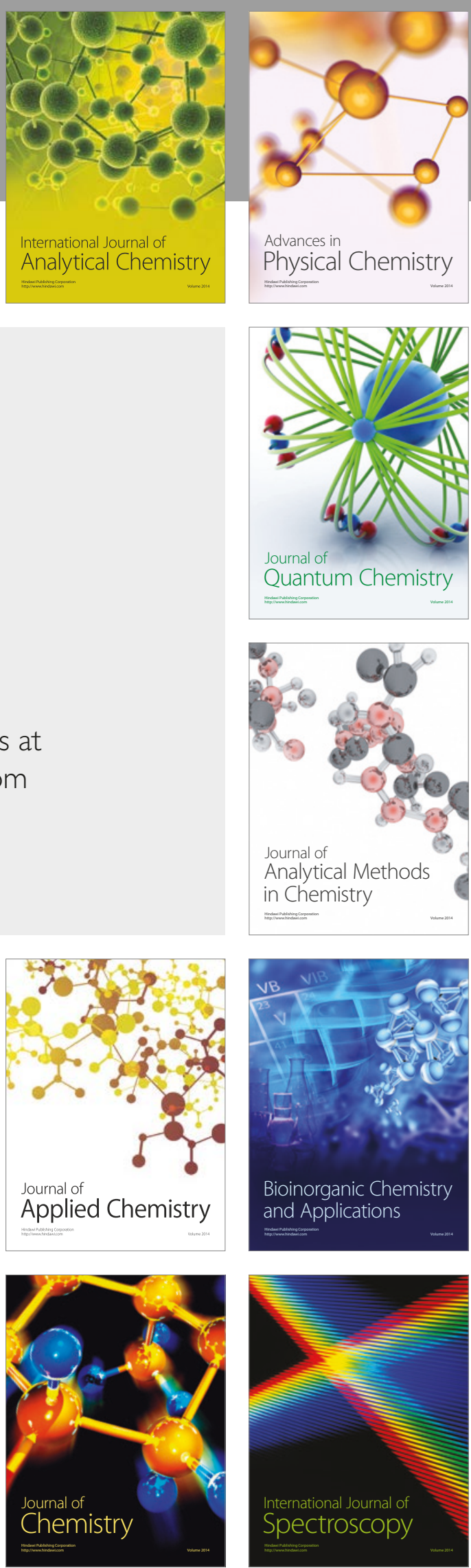